Research Note

\title{
Effects of Experience and Lactation on Lupine Consumption by Cattle
}

\author{
James A. Pfister, ${ }^{1}$ Stephen T. Lee, ${ }^{2}$ Kip E. Panter, ${ }^{3}$ Ernie S. Motteram, ${ }^{4}$ and Clive C. Gay ${ }^{5}$ \\ Authors are ${ }^{1}$ Rangeland Scientist, ${ }^{2}$ Research Chemist, and ${ }^{3}$ Reproductive Toxicologist, USDA-ARS Poisonous Plant Research Laboratory, Logan, UT \\ 84341, USA; and ${ }^{4}$ Rangeland Specialist and ${ }^{5}$ Professor Emeritus, College of Veterinary Medicine, Washington State University, Pullman, WA 99164,
} USA.

\begin{abstract}
Lupines (Lupinus spp.) are widespread range plants that are often toxic to livestock. Some reports suggest that naïve, younger animals might consume more lupine than more experienced, older cattle. Further, lactational stress might alter forage selection, and lactating cows might eat more lupine than nonlactating cows. Thus, the objectives of these trials were to examine the influence of experience and lactation on lupine intake. Both study areas were near Ritzville, Washington, on rangeland dominated by cheatgrass or downy brome (Bromus tectorum L.), with abundant velvet lupine (Lupinus leucophyllus Dougl.). During the first trial, six naïve and six experienced Hereford cows were grazed together for $25 \mathrm{~d}$ during summer. There was no difference $(P>0.5)$ in consumption of lupine by naïve and experienced cows. Consumption peaked at $10 \%-14 \%$ of daily bites. During the second trial, six lactating and six nonlactating cows grazed a lupine-infested pasture for $18 \mathrm{~d}$. There was no difference $(P>0.6)$ in consumption between lactating and dry cows. Lupine consumption gradually increased and peaked at $10 \%-15 \%$ of the diets. Our results suggest that experience and lactation status are probably minor considerations in livestock management schemes to reduce losses to lupine.
\end{abstract}

\section{Resumen}

Las plantas Lupinos (Lupinus spp.) se dan abundantemente en el pastizal y son con frecuencia tóxicas para el ganado. Algunos reportes sugieren que animales jóvenes y sin experiencia en pastoreo consumen más lupinos que animales adultos con experiencia. Además, el estrés lactacional en las hembras puede alterar la selección de forraje por lo que las vacas lactantes pueden consumir más lupinos que vacas no lactantes (secas). Estos estudios tuvieron como objetivo determinar la influencia tanto de la experiencia como del estado lactacional sobre el consumo de lupinos. El área de estudio se localiza cerca de Ritzville, WA en un pastizal dominado por Bromus tectorum L. (cheatgrass) con abundancia de lupinos (Lupinus leucophyllus Dougl.). Durante la primera prueba, seis vacas Hereford sin experiencia y seis con experiencia estuvieron pastoreando por 25 días durante el verano. No se encontraron diferencias $(P>0.5)$ en el consumo de lupinos en las vacas con y sin experiencia. El máximo consumo de lupinos se presentó del 10\% al 14\% del total de bocados al día. Durante la segunda prueba, seis vacas en lactación y seis vacas secas estuvieron pastoreando un potrero infestado de lupinos por 18 días. No se encontraron diferencias $(P>0.6)$ en el consumo de lupinos entre vacas lactantes y secas. El consumo de lupinos gradualmente se incrementó hasta un 10\%-15\% de la dieta. Estos resultados sugieren que la experiencia y estado lactacional de las vacas son probablemente consideraciones menores para reducir pérdidas causadas por lupinos durante la implementación de programas de manejo del ganado en pastoreo.

Key Words: birth defects, cattle diets, diet selection, Lupinus, poisonous plants

\section{INTRODUCTION}

Many species of lupine (Lupinus spp.) contain alkaloids such as anagyrine, which are toxic to livestock (Panter et al. 1999). Alkaloids in lupines often confer a bitter taste (to humans) as contrasted with low alkaloid "sweet" lupines (Vilarino et al. 2005), but livestock apparently graze lupines for nutritional benefits that outweigh deleterious effects (Provenza et al. 1992). Pregnant cattle that ingest toxic lupine (e.g., Lupinus caudatus Kellog, Lupinus sulphureus Dougl. ex Hook., Lupinus leucophyllus Dougl.) during gestation (days 40-70) often give birth to calves with lupine-induced arthrogryposis (i.e., crooked calf disease; Shupe et al. 1967; Panter et al. 1999). Keeler (1973) reported that anagyrine concentrations in

Correspondence: James A. Pfister, USDA-ARS Poisonous Plant Research Laboratory, 1150 E 1400 N, Logan, UT 84341, USA. Email: Jim.Pfister@ars.usda.gov

Manuscript received 20 October 2006; manuscript accepted 27 November 2007. excess of $0.14 \%$ are sufficient to cause crooked calves if consumption by cattle is sustained at a high, but unknown level, for about $1 \mathrm{wk}$. Two research reports indicate that the incidence of crooked calf disease is higher in first calf heifers (Shupe et al. 1967; Abbott et al. 1986), suggesting that age and/ or experience might influence lupine consumption or susceptibility. Further, lactation imposes nutritional stress on grazing cattle such that lactating cows might eat more lupine than do non-lactating cows. Thus, the purpose of these trials was to determine the effects of lactation and experience on consumption of velvet lupine (L. leucophyllus) by cattle.

\section{MATERIALS AND METHODS}

\section{Trial 1, 2003}

This trial was conducted near Ritzville, Washington, during summer 2003. The study area was dominated by downy brome 
(Bromus tectorum L.), with abundant velvet lupine. Six Hereford cows ( $3 \mathrm{yr}$ old, $342 \mathrm{~kg}$, raised in Nevada) naïve to lupine and to this region, and six Hereford cows (4-6 yr old, $493 \mathrm{~kg}$, raised $20 \mathrm{~km}$ from study area) with a lifetime of experience in this region were grazed for $25 \mathrm{~d}$ (13 June to 7 July) in a 6.6 -ha study pasture (lat $47^{\circ} 1.1^{\prime} \mathrm{N}$, long $118^{\circ} 6.7^{\prime} \mathrm{W}$, $500 \mathrm{~m}$ elevation). Cows were not pregnant. The study ended when lupine biomass was reduced and plants were beginning to senesce. All animal procedures were conducted under veterinary supervision and were approved by the Utah State University IACUC as protocol \#1142.

Forage availability was determined weekly by clipping 30 $0.25-\mathrm{m}^{2}$ quadrats placed along two pace transects $(1000 \mathrm{~m}$ long) through the pasture. Categories were green grass (i.e., graminoids), dry grass, fiddleneck (Amsinckia menziesii [Lehm.] Nels. and Macbr.), lupine, and other forbs. Clipped samples were placed into paper bags, and oven-dried at $60^{\circ} \mathrm{C}$ to a constant weight. An additional 10 random samples of each of the above categories were collected weekly throughout the pasture to augment amounts available for forage quality analyses. Density of lupine was determined at the beginning of the study by counting the number of plants in $3000.5-\mathrm{m}^{2}$ quadrats placed systematically every $15 \mathrm{~m}$ along three pace transects (1500 m long).

Daily bite counts were used to determine animal diets (Pfister et al. 1997). Beginning at 0515 hours every day, individual animals were focally sampled (Altmann 1974) in a predetermined random order. Each animal was observed in turn for 5 min. After all animals had been observed, the process was repeated during all active grazing periods until about 2000 hours, when cattle were placed in a corral for the night with water and salt. Bites were categorized as grasses, other forbs, and lupine flower, pod, leaf, leaf and stem, or whole plant. Typically each animal was observed for 30-40 min . $\mathrm{d}^{-1}$. Bite counts are not a measure of amount eaten, but show relative preference for different plant categories.

\section{Trial 2, 2004}

Six lactating and six non-lactating cows (4-6 yr old, $560 \mathrm{~kg}$ ) were grazed together near Ritzville, Washington, for $18 \mathrm{~d}$ on a 2.4-ha pasture divided into two equal units (lat $46^{\circ} 53.2^{\prime} \mathrm{N}$, long $118^{\circ} 7.5^{\prime} \mathrm{W}, 456 \mathrm{~m}$ elevation). All were Hereford cows from the same local ranch with a lifetime of experience in this region. Calves on lactating cows were approximately 6-8 wk old. The nonlactating cows were healthy herd animals that had failed to conceive the previous breeding season. Cattle grazed the first unit for $10 \mathrm{~d}$ ( 25 June to 4 July), and then were shifted into the second unit (5 July to 12 July) when lupine was depleted in the first unit. Bite counts, forage availability, and lupine density were measured as given above.

\section{Nutritional Quality and Alkaloid Analysis of Forage}

Forage samples were analyzed for nutritional quality using standard methods for neutral detergent fiber (NDF; Goering and Van Soest 1970), crude protein (CP; Wiles et al. 1998), and in vitro true digestibility (IVTD; Vogel et al. 1999).

Ten lupine plants at each phenological stage were harvested and composited by growth stage. These weekly samples were dried at $40^{\circ} \mathrm{C}$, ground through a $1-\mathrm{mm}$ screen, then analyzed for concentrations of the major teratogenic alkaloid, anagyrine (Gardner and Panter 1994).

\section{Statistical Analysis}

Each trial was examined separately as a completely randomized experimental design with two treatments. Data were examined for normality and, when necessary, an arcsine transformation was used for percentage data. The percentages of bites of lupine and the other forage classes were analyzed in a mixed linear model with treatments (naïve vs. experienced; lactating vs. nonlactating), cows nested within treatments, days as the repeated measure, and the day $\times$ treatment interaction. Animals and the repeated measures on individual subjects were random factors in the model. When there was a treatment $\times$ day interaction $(P<0.05)$, means were compared using the PDIFF option of Proc Mixed in SAS (2001). Individual animals were used as the experimental units even though animals grazed as a single herd in each trial; thus, social influences can not be distinguished from treatments. No statistical evaluation of forage quality or alkaloid concentration was done.

\section{RESULTS}

\section{Weather}

There was no rainfall during the 2003 trial, and a single rainfall event $(2.8 \mathrm{~mm})$ was recorded on 28 June 2004. Both trials encompassed periods of moderate drought. Average monthly precipitation totals for June and July at Ritzville are 187 and $140 \mathrm{~mm}$, respectively (NOAA 2002).

\section{Trial 1, 2003}

Lupine density was 0.9 plants $\cdot \mathrm{m}^{-2}$ at the start of the trial. Green grass biomass was reduced greatly from grazing and from grasses shifting into the dry grass category during the trial (Table 1). Lupine biomass also decreased from cattle consumption (Table 1); most of the available lupine in July was dry, partially grazed residual stems.

Naïve and experienced cows did not differ $(P>0.5)$ in consumption of lupine during summer 2003 (Fig. 1). Cattle ate little lupine during the first $10 \mathrm{~d}$, then consumption increased to $10 \%-14 \%$ of daily bites. Cattle began eating lupine as availability of green grass decreased. Consumption of dry grass increased markedly in the last $7 \mathrm{~d}$, peaking at over $50 \%$ of the diets.

Concentration of the major toxic alkaloid, anagyrine, varied in whole lupine plant material from $0.18 \%-0.26 \%$ during the 2003 trial (data not shown). Lupine plants were generally low in NDF $(49 \%-52 \%)$ and high in digestibility $(73 \%-76 \%)$. Lupine plants averaged $14.8 \%$ CP during the study, compared to $9.5 \%$ for other forbs and $6.1 \%$ for dry grasses.

\section{Trial 2, 2004}

Lupine density was 1.2 and 2.1 plants $\cdot \mathrm{m}^{-2}$ in the first and second pasture, respectively, at the beginning of the trial. Green grasses were essentially nonexistent, whereas forbs and dry grass were abundant. Forbs in particular were not depleted by cattle grazing during this trial. Virtually all the remaining lupine in the first pasture on 4 July was residual, 
Table 1. Forage availability ( $\mathrm{kg} \cdot \mathrm{ha}^{-1} \pm \mathrm{SE}$ ) during lupine grazing studies near Ritzville, Washingtong, during summers of 2003 and 2004.

\begin{tabular}{|c|c|c|c|c|c|}
\hline Year/Date & Dry grass & Green grass ${ }^{1}$ & Other forbs & Fiddleneck & Lupine \\
\hline & ----- & 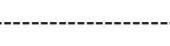 & $-\mathrm{kg} \cdot \mathrm{ha}^{-1}$ & 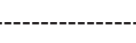 & ----------- \\
\hline \multicolumn{6}{|l|}{2003} \\
\hline 13 June & $51 \pm 15$ & $313 \pm 61$ & $256 \pm 78$ & $283 \pm 83$ & $202 \pm 77$ \\
\hline 20 June & $94 \pm 24$ & $148 \pm 42$ & $295 \pm 68$ & $105 \pm 29$ & $116 \pm 36$ \\
\hline 5 July & $116 \pm 13$ & $3 \pm 2$ & $157 \pm 48$ & $91 \pm 36$ & $70 \pm 26$ \\
\hline \multicolumn{6}{|l|}{2004} \\
\hline 25 June & $847 \pm 101$ & - & $1078 \pm 166$ & - & $172 \pm 87$ \\
\hline 4 July & $425 \pm 75$ & - & $881 \pm 149$ & - & $14 \pm 10$ \\
\hline 12 July $^{2}$ & $218 \pm 37$ & - & $924 \pm 134$ & - & $71 \pm 34$ \\
\hline
\end{tabular}

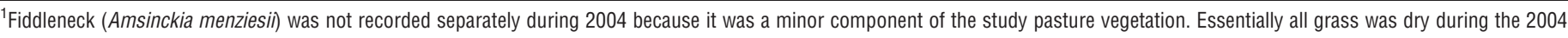
trial.

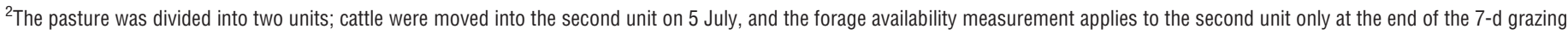
period.

partially grazed stems; after moving cattle to an ungrazed pasture, lupine was quickly depleted in this pasture as well (Table 1).

In the first pasture, cattle began eating lupine on day 4 and consumption generally increased until day 9 (Fig. 1) when lupine availability was very low (Table 1 ). There was no difference $(P>0.6)$ in consumption between lactating and dry cows. Lupine consumption peaked at $10 \%-15 \%$ of the diets. Cattle were then switched to the next pasture and grazed there for $9 \mathrm{~d}$ until lupine availability was again very low. Cattle ate mostly grasses on the first day after switching paddocks, then lupine consumption averaged $5 \%-15 \%$ of diets during the remainder of the trial (Fig. 1). Other forbs composed the majority $(60 \%-70 \%)$ of the diets, and consumption of dry grass varied from approximately $10 \%$ to $20 \%$ of the diets.

Anagyrine concentration in lupine ranged from $0.10 \%$ to $0.19 \%$ during late June to mid-July 2004. Lupine plants averaged $58.1 \% \mathrm{NDF}, 13.2 \% \mathrm{CP}$, and $59.4 \%$ IVTD during most of the trial, although residual ungrazed lupine stems contained only $6.7 \% \mathrm{CP}$ at the end of the study. Dry grasses and forbs averaged $5.1 \%$ and $5.8 \% \mathrm{CP}$, respectively, over the study period.

\section{DISCUSSION}

The 2003 trial showed essentially no differences in lupine consumption between naïve and experienced cows. Two research reports indicate that the incidence of crooked calf disease is higher in first-calf heifers (Shupe et al. 1967; Abbott et al. 1986), suggesting that age and/or experience influence lupine consumption or susceptibility. Animals in the two treatments were all mature, although naïve animals were younger, thus potentially confounding the study. The treatment groups differed greatly in experience. Experience might have a profound effect on diet selection, because experienced animals might ingest more of a specific plant than naïve animals when exposed later in life (Distel and Provenza 1991; Olson et al. 1996). Conversely, experienced animals might sample then refuse some toxic plants based on adverse postingestive consequences (Provenza et al. 1992). Experienced sheep in South Africa refused to eat Senecio spp. after $4 \mathrm{~d}$ exposure, even when starving (Kellerman et al. 1988). Cattle given a sublethal sample of Moraea pallida (Baker) Goldblatt then refused to eat the plant (Strydom and Joubert 1983). Only naïve cattle in southern Brazil were poisoned by Baccharis cordifolia DC because experienced animals learned to avoid the plant (Tokarnia et al. 2000). Nonetheless, our trial suggests that experience is not a major factor in consumption of lupine under these circumstances. In support of our findings, Gay et al. (2007) reported that recent region-wide surveys revealed no age-specific trend in birth defects.

Previous research showed that the physiological state of cows, specifically body condition, influenced lupine consumption on these rangelands (Lopez-Ortiz et al. 2007). Milne et al. (1981) found that lactating sheep had greater forage intakes than did dry sheep. Lactation is nutritionally stressful for grazing cattle, particularly on ranges with mostly low quality forages. Even so, this trial suggested that lactation did not influence cattle to eat more lupine.

In this study design, animals from both treatments grazed together, because we did not have sufficient animals or pastures to use another design. It is possible that treatment effects were obscured by social influences, although our personal observations do not support this view. Social influences might alter diet selection by increasing preference for foods that were previously avoided (Ralphs and Olsen 1990; Thorhallsdottir et al. 1990; Ralphs et al. 1994). However, Bailey et al. (2000) reported that social facilitation primarily influenced cattle feeding locations, not specific dietary choices. We contend that social facilitation was not a major factor because 1) lupine was widespread in the pastures, 2) lupine consumption was low for all animals during most of the trials, and 3) the increase in lupine bite counts later in the trials closely mirrored results from other studies (Ralphs et al. 2006; Lopez-Ortiz et al. 2007). Nonetheless, the findings from this study must be taken with caution until corroborated by further study.

\section{IMPLICATIONS}

These trials suggest that naïve or lactating cattle do not eat more lupine than experienced or dry cows; thus, other factors must be considered in managing lupine-infested rangelands. Cheatgrass-dominated rangelands in this region generally provide low quality nutritional choices for cattle. Lupines 

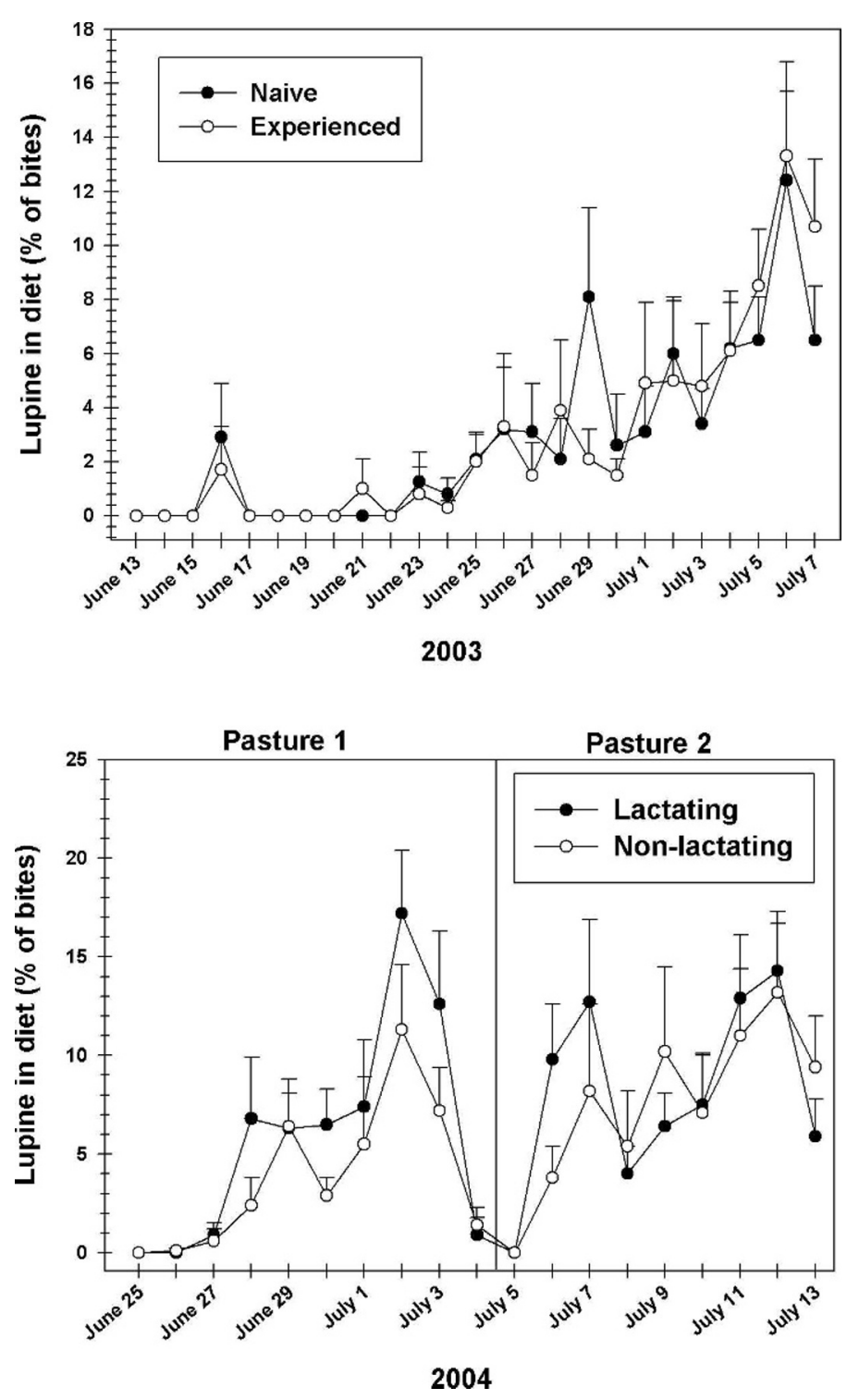

Figure 1. Consumption of lupine (\% of bites) by cattle during two trials in 2003 and 2004 near Ritzville, Washington. The first trial during 2003 compared naïve vs. experienced cattle; there were no differences between treatments $(P>0.5)$ for lupine consumption, but there were day effects $(P<0.05)$. The second trial during 2004 compared lactating and nonlactating cows. There were no differences between treatments $(P>0.5)$ for lupine consumption during the 2004 trial; there were day effects $(P<0.05)$. During the 2004 trial, cattle were moved from Pasture 1 when lupine was depleted, and moved into a new pasture with abundant lupine on 5 July 2004.

typically contain $>14 \%$ crude protein and are often nutritionally superior to other forage choices. Lupine consumption by cattle typically peaks in midsummer when other forage has desiccated, and this period of consumption often coincides with early gestation. Livestock producers with persistent problems with calves born with birth defects should plan grazing management to reduce or avoid exposure to lupine-infested pastures during gestation, days 40-70. It is not known exactly how much or for how long cattle must ingest lupine to cause birth defects; thus, cautious managers can reduce incidents of birth defects by altering either the breeding season or exposure by pregnant cattle to lupine during the sensitive period of gestation.

\section{ACKNOWLEDGMENTS}

We thank Kermit Price, Dr Dale Gardner, Dr Jeff Hall, Al Maciulis, Rex Probst, and Danny Hansen for assistance.

\section{LITERATURE CITED}

Аввott, L. C., R. H. Finnell, G. F. Chernoff, S. F. Parish, and C. C. Gay. 1986. Crooked calf disease: a histological and histochemical examination of eight affected calves. Veterinary Pathology 23:734-740.

Altmann, J. 1974. Observational study of behavior: sampling methods. Behaviour 49:227-267.

Bailey, D. W., L. D. Howery, and D. L. Boss. 2000. Effects of social facilitation for locating feeding sites by cattle in an eight-arm radial maze. Applied Animal Behaviour Science 68:93-105.

Distel, R. A., and F. D. Provenza. 1991. Experience early in life affects voluntary intake of blackbrush by goats. Journal of Chemical Ecology 17:431-450.

Gardner, D. R., and K. E. Panter. 1994. Ammodendrine and related piperidine alkaloid levels in the blood plasma of cattle, sheep and goats fed Lupinus formosus. Journal of Natural Toxins 3:107-116.

Gay, C. C., K. E. Panter, E. Motteram, J. M. Gay, H. Hantz, T. Wierenga, and T. Platt. 2007. Risk factors for lupine-induced crooked calf disorder in east-central Washington state. In: K. E. Panter, T. Wierenga, and J. Pfister [Eds.]. Poisonous plants: global research and solutions. Wallingford, United Kingdom: CABI Publishing. p. 156-164.

Goering, H. K., and P. J. Van Soest. 1970. Forage fiber analysis (apparatus, reagents, procedures, and some applications). USDA-ARS Agricultural Handbook 379. Washington, DC, USA: US Government Printing Office. $20 \mathrm{p}$.

KeELER, R. F. 1973. Lupine alkaloids from teratogenic and nonteratogenic lupines. I. Correlation of crooked calf disease incidence with alkaloid distribution determined by gas chromatography. Teratology 7:23-30.

Kellerman, T. S., J. A. W. Coetzer, and T. W. Naude. 1988. Plant poisonings and mycotoxicoses of livestock in southern Africa. Cape Town, South Africa: Oxford University Press. 243 p.

Lopez-Ortiz, S., J. A. Pfister, K. Launchbaugh, and C. Gay. 2007. Effects of forage availability and body condition on intake of lupine (Lupinus leucophyllus) by grazing cattle. Professional Animal Scientist 23:459-466.

Milne, J. A., T. J. Maxwell, and W. G. Souter. 1981. The effect of supplementary feeding and herbage mass on the intake and performance of grazing ewes in early lactation. Animal Production 32:185-195.

NOAA. 2002. Climatography of the United States No. 81, 1971-2000: monthly normals. Asheville, NC, USA: National Oceanographic and Atmospheric Administration National Climatic Data Center. Available at: www5. ncdc.noaa.gov/cgi-bin/climatenormals/climatenormals.pl. Accessed 18 April 2006.

Olson, B. E., R. T. Wallander, V. M. Thomas, and R. W. Kott. 1996. Effect of previous experience on sheep grazing leafy spurge. Applied Animal Behaviour Science 50:161-176.

Panter, K. E., L. F. James, and D. R. Gardner. 1999. Lupines, poison hemlock and Nicotiana spp.: toxicity and teratogenicity in livestock. Journal of Natural Toxins 8:117-134.

Pfister, J. A., M. H. Ralphs, G. D. Manners, D. R. Gardner, K. W. Price, and L. F. James. 1997. Early season grazing of tall larkspur- (Delphinium spp.) infested rangelands. Journal of Range Management 50:391-398.

Provenza, F. D., J. A. Pfister, and C. D. Cheney. 1992. Mechanisms of learning in diet selection with reference to phytotoxicosis in herbivores. Journal of Range Management 45:36-45. 
Ralphs, M. H., D. Graham, and L. F. James. 1994. Social facilitation influences cattle to graze locoweed. Journal of Range Management 47:123-126.

Ralphs, M. H., AND J. D. Olsen. 1990. Adverse influence of social facilitation and learning context in training cattle to avoid eating larkspur. Journal of Animal Science 68:1944-1952.

Ralphs, M. H., K. E. Panter, C. C. Gay, E. S. Motteram, and S. T. Lee. 2006. Cattle consumption of velvet lupine (Lupinus leucophyllus) in the Channel Scablands of eastern Washington. Rangeland Ecology \& Management 59:204-207.

SAS. 2001. Statistical Analysis System, SAS/STAT users guide. Version 8. Cary, NC, USA: SAS Institute. 1,464 p.

Shupe, J. L., W. Binns, L. F. James, and R. F. Keeler. 1967. Lupine, a cause of crooked calf disease. Journal of the American Veterinary Medical Association 151:198-203.

Strydom, J. A., AND J. P. L. Joubert. 1983. The effect of predosing Homeria pallida Bak. to cattle to prevent poisoning. Journal of South African Veterinary Association 54:201-203.
Thorhallsdottir, A. G., F. D. Provenza, and D. F. Balph. 1990. Ability of lambs to learn about novel foods while observing or participating with social models. Applied Animal Behaviour Science 25:25-33.

Tokarnia, C. H., J. Döbereiner, and P. V. Peixoto. 2000. Plantas tóxicas do Brasil (in Portuguese). Rio de Janeiro, Brazil: Editora Helianthus. $310 p$

Vilarino, M. del P., G. Mareggiani, M. Y. Grass, S. R. Leicach, and D. A. Ravetta. 2005. Post-damage alkaloid concentration in sweet and bitter lupin varieties and its effect on subsequent herbivory. Journal of Applied Entomology 129:233-238.

Vogel, K. P., J. F. Pedersen, S. D. Masterson, and J. J. Toy. 1999. Evaluation of a filter bag system for NDF, ADF, and IVDMD forage analysis. Crop Science 39:276-279.

Wiles, P. G., I. K. Gray, and R. C. Kissuing. 1998. Routine analysis of proteins by Kjeldahl and Dumas methods: review and interlaboratory study using dairy products. Journal of Association of Official Analytical Chemists 81: 620-632. 